Original

\title{
Dye decomposition by combined ozonation and anaerobic treatment: Cost effective technology
}

\author{
Smita Venkatesh ${ }^{\mathrm{a}, *}$, Kumar Venkatesh ${ }^{\mathrm{b}}$, Abdur Rahman Quaff ${ }^{\mathrm{c}}$ \\ ${ }^{a}$ Department of Chemistry, Motilal Nehru National Institute of Technology, Allahabad, India \\ ${ }^{\mathrm{b}}$ Department of Civil Engineering, Motilal Nehru National Institute of Technology, Allahabad, India \\ ${ }^{\mathrm{c}}$ Department of Civil Engineering, National Institute of Technology, Patna, India
}

Received 12 August 2016; accepted 23 February 2017

Available online 31 July 2017

\begin{abstract}
To control the total treatment cost of textile dye effluent a new advanced combined treatment technology has been investigated. Advanced oxidation processes like ozonation have much potential to degrade dye but its main drawback is high cost. To reduce the cost of ozonation for dye degradation and decolourization, ozonation followed by anaerobic biodegradation using upflow anaerobic sludge blanket (UASB) reactor was carried out. The synthetic textile wastewater containing Reactive Black 5 has been used in this study by this combined treatment process. The system of ozonation and anaerobic treatment by UASB reactor showed that the chemical oxygen demand (COD) reduction has reached to about $90 \%$ and dye removal $94 \%$ respectively. Combined treatment enhanced the overall color removal up to 10 on platinum cobalt (Pt-Co) scale. Thus the combined treatment process results in high color, COD and total organic carbon (TOC) removal efficiency which would minimize the overall treatment cost. Dye degradation products were analyzed by ion chromatography (IC) and UV-vis spectroscopy.

(C) 2017 Universidad Nacional Autónoma de México, Centro de Ciencias Aplicadas y Desarrollo Tecnológico. This is an open access article under the CC BY-NC-ND license (http://creativecommons.org/licenses/by-nc-nd/4.0/).
\end{abstract}

Keywords: Reactive Black 5; Decolourization; Degradation; Ozonation; Anaerobic biodegradation; UASB reactor

\section{Introduction}

Ozonation as pre-treatment of textile dye wastewater is an efficient step for improving wastewater biodegradability, as well as reducing acute ecotoxicity, which can be removed completely through sequential biological treatment (Somensi, Simionatto, Bertoli, Wisniewski, \& Radetski, 2010). Abidin, Fahmi, SoonAn, Makhtar, and Rahmat (2015) reported that the application of ozonation as pre-treatment for biological treatment may further mineralize the dye-containing wastewater. COD was reduced simultaneously by ozonation and biological treatment mechanism at lower ozone doses (Abidin \& Ridwan, 2011). Punzi et al. (2015) used anaerobic biofilm reactor followed by ozonation for treatment of textile wastewater containing azo dyes. In combined treatment, ozonation and biological method

\footnotetext{
* Corresponding author.

E-mail address: smita.venkatesh@gmail.com (S. Venkatesh).

Peer Review under the responsibility of Universidad Nacional Autónoma de México.
}

in wastewater, ozone removed COD, color and pathogens and increased the biodegradability of the wastewater (De Souza, Bonilla, \& De Souza, 2010).

A new combined treatment process, ozonation and anaerobic biodegradation by UASB reactor has been proposed to see the degradation effect of dye wastewater, so that an efficient and economical, wastewater treatment system could be generated.

\section{Materials and methods}

Reactive Black 5 as di-azo dye synthetic solution was used for making synthetic wastewater. The concentration and $\mathrm{pH}$ of dye wastewater were very high i.e. $1500 \mathrm{mg} / \mathrm{L}$ and 10.13 . Figure 1 shows the chemical structure of Reactive Black 5. Ozone was generated by corona discharge type ozone generator model Eltech el- $5 \mathrm{~g} / \mathrm{h}$.-A with flow rate of $5 \mathrm{~g} / \mathrm{h}$. Ozonation of dye solution was carried out in a batch mode. Detail ozonation procedure including decomposition mechanism and experimental analyses have been described in earlier work (Venkatesh, Quaff, Venkatesh, \& Pandey, 2014). 
<smiles>NOS(=O)(=O)OCCS(=O)(=O)c1ccc(N=Nc2c(S(=O)(=O)O)cc3cc(S(=O)(=O)O)c(N=Nc4ccc(S(=O)(=O)CCOS(=O)(=O)O[Na])cc4)c(O)c3c2N)cc1</smiles>

Fig. 1. Chemical structure of Reactive Black 5.

The biological analysis was performed in a lab scale upflow anaerobic sludge blanket (UASB) reactor shown in Figure 2. The biomass in the UASB reactor was conditioned sludge. This conditioned sludge was prepared using fresh sludge fed with synthetic media containing $500 \mathrm{mg} / \mathrm{L}$ sucrose for 30 days in a laboratory. The fresh sludge was obtained from the anaerobic digester tank of full-scale activated sludge process based sewage treatment plant at Bakshibandh, Allahabad, India. Reactor was fed by synthetic wastewater containing sucrose as carbon source whose COD was $534 \mathrm{mg} / \mathrm{L}$ up to steady state condition achieved. The flow rate was $25 \mathrm{~mL} / \mathrm{h}$, which translated to up flow velocity $0.16 \mathrm{~m} / \mathrm{h}$ and hydraulic retention time (HRT) of $40 \mathrm{~h}$. Yasar and Tabinda (2010) reported UASB reactor performs better removal efficiency at lower hydraulic retention time. After achieving a steady state condition, the reactor was continuously running on synthetic medium strength domestic wastewater. After that, the reactor was subjected to ozonated synthetic dyes solutions. The ozonated azo dye solutions were mixed with synthetic wastewater in a 1:1 ratio. For determination of the extent of anaerobic biodegradation, mixed ozonated azo dye solutions were used as feed for anaerobic bacteria and assessed for the extent of biodegradability in UASB reactor.

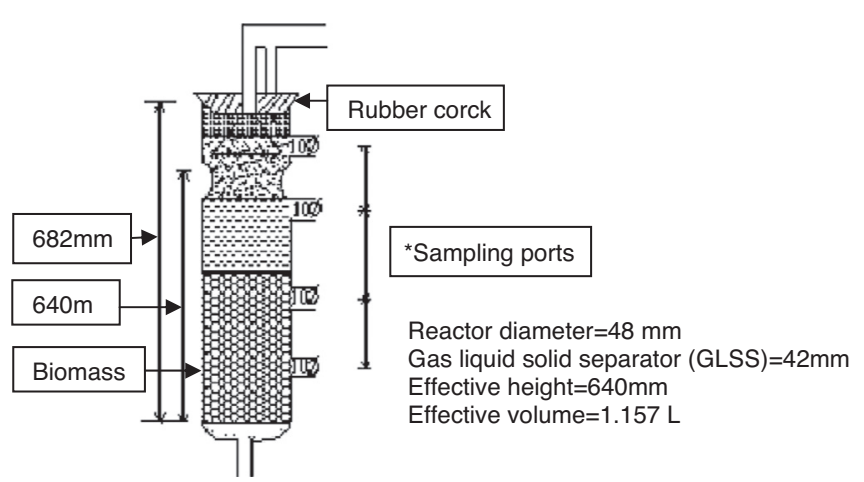

Fig. 2. Schematic diagram of UASB reactor.

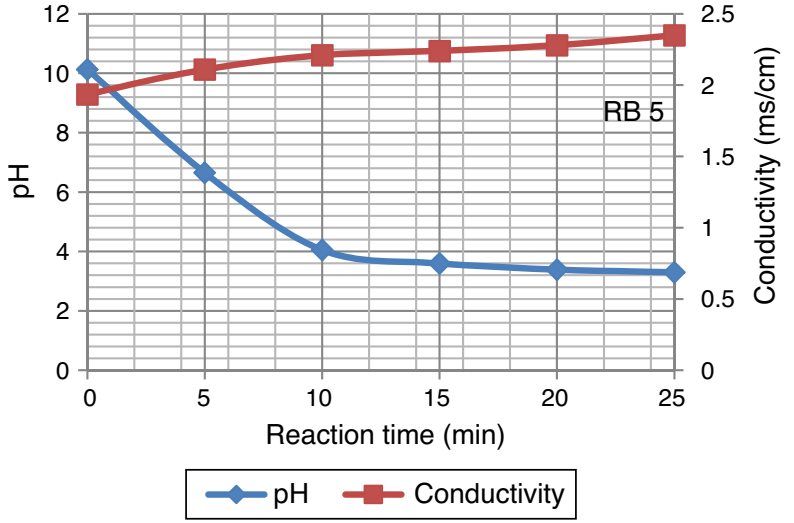

Fig. 3. Variation in $\mathrm{pH}$ and conductivity at $25^{\circ} \mathrm{C}$ with ozonation time for initial dye concentration of $1500 \mathrm{mg} / \mathrm{L}$ of Reactive Black 5 .

\section{Results and discussion}

\subsection{Effect of ozonation on dye wastewater}

Decline in $\mathrm{pH}$ value of Reactive Black 5 dye samples were observed during ozonation. This decreases rapidly from 10.13 to 3.30 in 25 min whereas conductivity of dyes solution increased during ozonation. Increase in conductivity after ozonation may partly be attributed to an indirect confirmation of ion accumulation. Figure 3 displays the variation in $\mathrm{pH}$ and conductivity at $25^{\circ} \mathrm{C}$.

After $25 \mathrm{~min}$ of ozonation the initial concentration of dye wastewater reduced from $1500 \mathrm{mg} / \mathrm{L}$ to $97.4 \mathrm{mg} / \mathrm{L}$. The degradation of high concentration Reactive Black 5 dye molecules required longer ozonation time. Ozonation of dye solution reduced the COD concentration. 50\% COD reduction occurred in 10 min of ozonation time, although in some cases the values of COD increase with ozonation time. An increase in COD value was mainly because of an organic species produced due to destruction of the molecular structure of azo dye by ozone (Constapel, Schellentriager, Marzinkowski, \& Gab, 2009; Venkatesh, Quaff, Venkatesh, \& Pandey, 2015). Figure 4 presents the dye concentration and COD decline during ozonation of Reactive Black 5 dye solution. Fahmi, Abidin, and

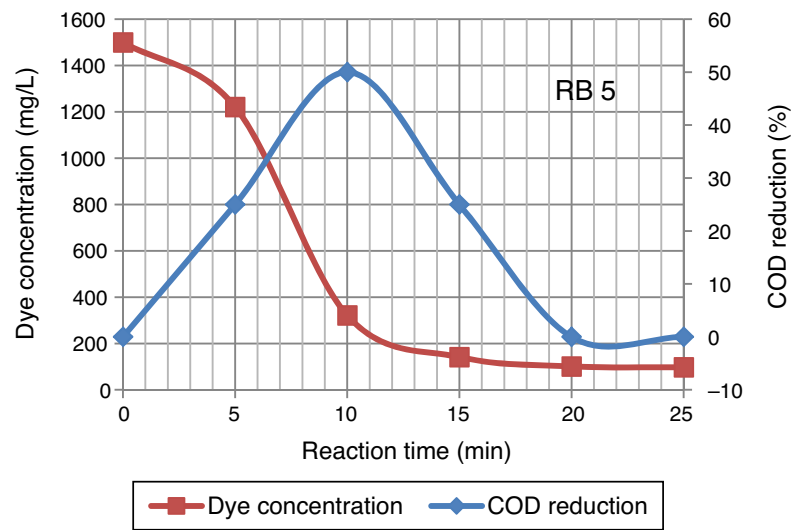

Fig. 4. Reduction in the dye concentration and COD during ozonation of Reactive Black 5 dye solution. 


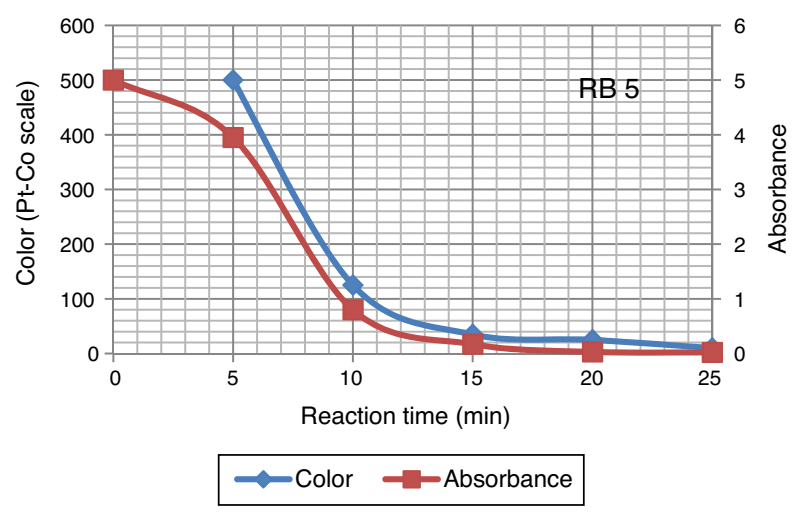

Fig. 5. Decolouration dynamics of azo dye solution.

Rahmat (2011) reported increases of COD were observed during ozonation process due to dye molecules being oxidized resulting in formation of small organic molecular fragments, such as acetic acid, aldehydes, ketones, which are not completely mineralized under the oxidative conditions, contributing to the increase in COD.

Color of dye solution was declining exponentially with increase ozonation time. It achieved around $70 \%$ decolourization in $10 \mathrm{~min}$. Decolourization efficiency was $94 \%$ after $25 \mathrm{~min}$ of ozonation investigated in this study. Ozonation treatment leads to a complete decolourization of the Acid Black 1 dye solution in 25 min (Paprocki, Dos Santos, Hammerschitt, Pires, \& Azevedo, 2010). A rapid decline in color (Pt-Co scale) and absorbance shows that the decolouration dynamics in Figure 5. In Reactive Black 5 azo dye solution, ozonation resulted in progressive increases in biodegradability ratio. It increased from 0 to 0.4 after 25 min of ozonation. The extent of mineralization of dye molecules can be explained by the reduction in TOC content due to ozonation. During ozonation, the dye molecules being oxidize and mineralize by attack of ozone on aromatic rings and unsaturated sites on dye molecules. The TOC of azo dye solutions before and after ozonation was 173.94 and $132.2 \mathrm{mg} / \mathrm{L}$ respectively. Other researchers (Gharbani, Tabatabaii, \& Mehrizad, 2008; Tehrani-Bagha, Mahmoodi, \& Menger, 2010) have also observed similar results in reduction of TOC by ozonation of dye solutions. Sundrarajan, Vishnu, and Joseph (2007) reported $50 \%$ COD and $40 \%$ TOC reduction were achieved by ozonation from a dye bath effluent containing several conventional reactive dyes of different shades.

\subsection{Mineralization of ozonated azo dye solutions in UASB reactor}

To determine the extent of anaerobic biodegradation by anaerobic bacteria in UASB reactor, the dye solutions after ozonation were mixed with synthetic wastewater in a 1:1 ratio and used as feed for anaerobic bacteria in UASB reactor. The results demonstrated that the UASB reactor performance varied from 60 to $83 \%$ for COD reduction. The reactor was operated at low organic loading rate $0.1-0.2 \mathrm{~kg} \mathrm{COD} / \mathrm{m}^{3} \mathrm{~d}$. The influent COD was $478.0 \pm 3.00 \mathrm{mg} / \mathrm{L}$. No significant variations in the effluent characteristics were observed. The COD of the UASB

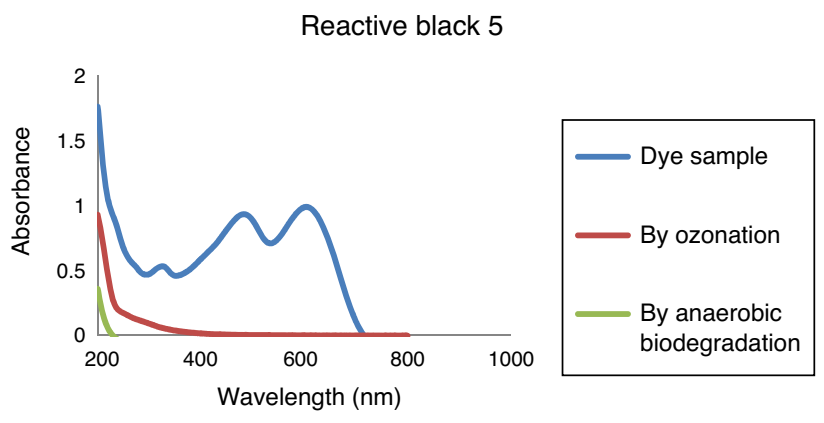

Fig. 6. UV-vis spectrum variations of Reactive Black 5 dye.

Table 1

Analysis of by-products of Reactive Black 5 dye solution.

\begin{tabular}{lll}
\hline $\begin{array}{l}\text { Inorganic/organic ions } \\
\text { concentration }(\mathrm{mg} / \mathrm{L})\end{array}$ & After ozonation & After anaerobic biodegradation \\
\hline Sulphate & 134.11 & 55.22 \\
Nitrate & 19.63 & 18.48 \\
Nitrite & $\mathrm{ND}$ & 0.26 \\
Fluoride & 1.2 & 0.48 \\
Chloride & 525.93 & 266.83 \\
Phosphate & $\mathrm{ND}$ & 15.16 \\
Oxalate & 107.53 & $\mathrm{Nil}$ \\
\hline
\end{tabular}

effluent was $40.29 \pm 2.46 \mathrm{mg} / \mathrm{L}$. Changes in $\mathrm{pH}$ and alkalinity were insignificant. Ganesh, Ramasamy, Gajalakshmi, Sanjeevi, and Abbasi (2007) observed the UASB reactors achieved total organic removal efficiency of $75-85 \%$.

\subsection{Analysis of removal of organic compounds by combined process}

The degradation of azo dye was monitored, by the study of the absorbance of the untreated and treated dye sample in UV absorbance range from 200 to $1000 \mathrm{~nm}$. Figure 6 shows the UV-vis spectrum variations of Reactive Black 5 dye solutions. Results indicate that the dye is destroyed by ozone very rapidly. The specified wavelength peak $\left(\lambda_{\max } 600 \mathrm{~nm}\right)$ has been found to disappear and a continuous decrease in absorbance has been observed. From results, it signifies that the ozone-oxidation can remove the organics present in the dye wastewater samples. When ozonated dye solution were further treated through anaerobic process, it is observed that the absorbance at those wavelength is less compared to the absorbance after ozoneoxidation stage, which signify that the remaining organics are also being removed by anaerobic process. Fahmi, Abidin, and Rahmat (2010) observed ozonation transforms the functional groups in azo dye to produce more biodegradable by products, which are easily removed by biological treatment.

\subsection{By-products identification by ion chromatography}

The products formation after combined treatment of azo dye solutions were identified by ion chromatography and are presented in Table 1. Chromatogram of this analysis is presented in Figure 7. These ions found after ozone treatment were also 


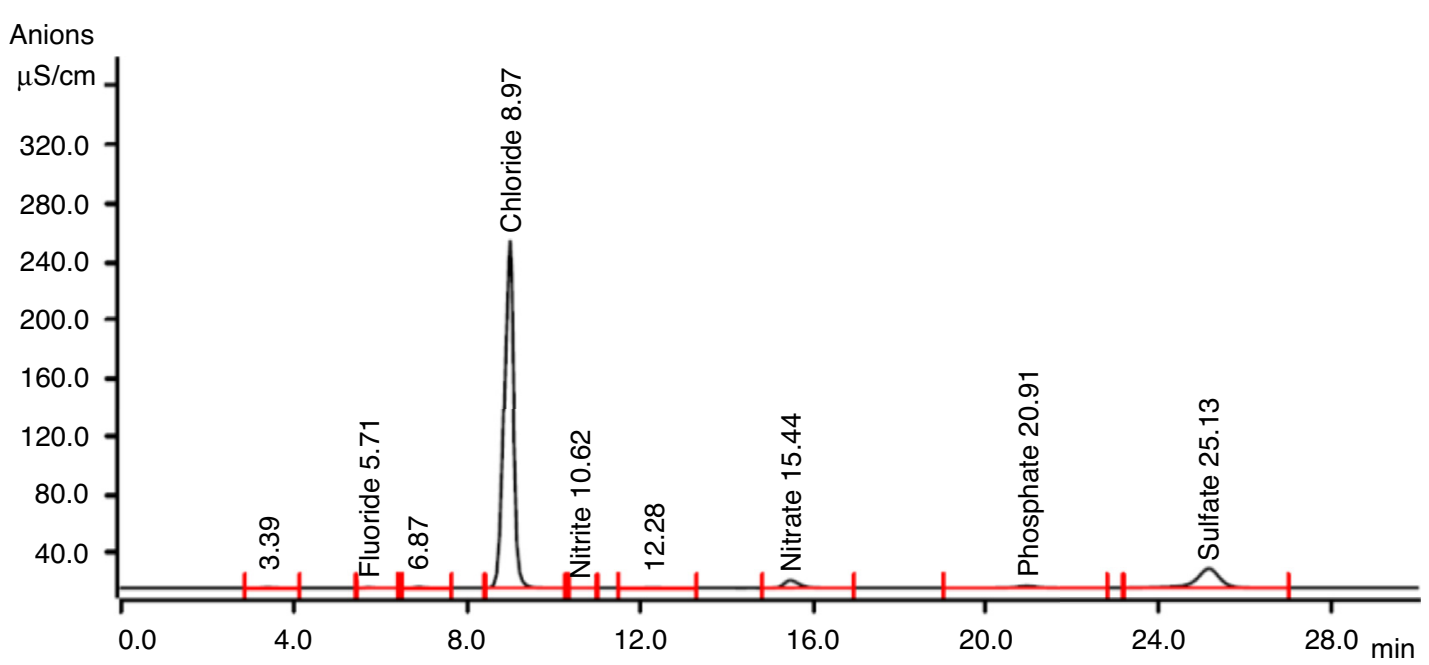

Fig. 7. Ions chromatogram after anaerobic process of azo dye solution.

present after anaerobic biodegradation in very low concentrations. Anaerobic biodegradation in UASB reactor resulted in complete mineralization of oxalate ions. During ozonation, the cleavage of the dye results in aromatic amines and their further oxidation/ozonation leads to organic acids. Further ozonation resulting oxidation and cleavage of amine groups $\left(\mathrm{NH}_{2}\right)$ in the original dye molecules were oxidized to nitrate. Oxidation and cleavage of sulphonic groups result in the formation of sulphate observed in this study.

The degradation mechanism of ozonation in dye molecules, leading to the release of benzene and naphthalene derivatives as ozonation by-products which further oxidize in aldehydes, ketones and other aliphatic compounds was observed by Zhang, Yediler, and Liang (2007) and Zhu (2010). Ozonation of azo dye solutions resulted in formation of aromatic and aliphatic compounds, which are further degraded by anaerobic biodegradation and shows enhanced $\mathrm{BOD}_{5} / \mathrm{COD}$ ratio.

The decomposition of ozone in water is the chain mechanism which is combined with initiation, propagation, and termination. The oxidation occurs through highly reactive hydroxyl radicals. These free radicals come from reaction mechanism. Such free radicals are readily available to react instantly with organic compounds such as dyes (Alvarez, Pocostales, \& Beltran, 2011; Siles, García-García, Martín, \& Martín, 2011). Buehler, Staehelin, and Hoigne (1984) proved experimentally that the hydroxyl radicals are dominant decomposition products of ozone in aqueous solutions, and accelerate the decomposition of ozone. Ozone reaction is more inclined to direct reaction with increasing the inhibitor concentration (Guo, Yang, Cheng, \& Wang, 2012).

A simple mechanism for the decomposition of ozone in aqueous solution is illustrated in following Eq. (Selcuk, 2005).

$$
\begin{aligned}
& \mathrm{O}_{3}+\mathrm{OH}^{-} \rightarrow \mathrm{HO}_{2}^{\bullet}+\mathrm{O}_{2}^{-\bullet} \\
& \mathrm{O}_{3}+\mathrm{HO}_{2}^{\bullet} \rightarrow \mathrm{OH}^{\bullet}+2 \mathrm{O}_{2} \\
& \mathrm{O}_{3}+\mathrm{OH}^{\bullet} \rightarrow \mathrm{O}_{3}^{\bullet}+\mathrm{OH}^{\bullet} \\
& \mathrm{O}_{3}^{\bullet} \rightarrow \mathrm{O}^{\bullet}+\mathrm{O}_{2}
\end{aligned}
$$

$$
\begin{aligned}
& \mathrm{O}^{\bullet}+\mathrm{H}^{+} \rightarrow \mathrm{OH}^{\bullet} \\
& \mathrm{OH}^{\bullet}+\mathrm{HO}_{2}^{\bullet} \rightarrow \mathrm{H}_{2} \mathrm{O}+\mathrm{O}_{2}
\end{aligned}
$$

Hoigne, Staehelin and Bader (HSB) model, has described the decomposition process of ozone in aqueous solution. The decomposition routes of ozone with reaction rate constants are following equation (Staehelin \& Hoigne, 1985; Langlais, Reckhow, \& Brink, 1991):

$$
\begin{aligned}
& \mathrm{O}_{3}+\mathrm{OH}^{-} \rightarrow \mathrm{HO}_{2}^{\bullet}+\mathrm{O}_{2}^{-\bullet}, \quad k=70 \mathrm{M}^{-1} \mathrm{~s}^{-1} \\
& \mathrm{O}_{3}+\mathrm{O}_{2}^{-\bullet} \rightarrow \mathrm{O}_{2}+\mathrm{O}_{3}^{-\bullet}, \quad k=1.6 \times 10^{9} \mathrm{M}^{-1} \mathrm{~s}^{-1} \\
& \mathrm{H}^{+}+\mathrm{O}_{3}^{-\bullet} \leftrightarrow \mathrm{HO}_{3}, \quad \mathrm{pK}=10.3 \\
& \mathrm{HO}_{3}^{\bullet} \rightarrow \mathrm{HO}^{\bullet}+\mathrm{O}_{2}, \quad k=1.1 \times 10^{5} \mathrm{M}^{-1} \mathrm{~s}^{-1} \\
& \mathrm{HO}^{\bullet}+\mathrm{O}_{3} \rightarrow \mathrm{HO}_{4}^{\bullet}, \quad k=2.0 \times 10^{9} \mathrm{M}^{-1} \mathrm{~s}^{-1} \\
& \mathrm{HO}_{4}^{\bullet} \rightarrow \mathrm{HO}_{2}^{\bullet}+\mathrm{O}_{2}, \quad k=2.8 \times 10^{4} \mathrm{M}^{-1} \mathrm{~s}^{-1} \\
& 2 \mathrm{HO}_{4}^{\bullet} \rightarrow \mathrm{H}_{2} \mathrm{O}_{2}+2 \mathrm{O}_{3}, \quad k=5 \times 10^{9} \mathrm{M}^{-1} \mathrm{~s}^{-1} \\
& \mathrm{HO}_{4}^{\bullet}+\mathrm{HO}_{3}^{\bullet} \rightarrow \mathrm{H}_{2} \mathrm{O}_{2}+\mathrm{O}_{3}+\mathrm{O}_{2}, \quad k=5 \times 10^{9} \mathrm{M}^{-1} \mathrm{~s}^{-1}
\end{aligned}
$$

In the present study, the absorbance decreases (Fig. 5) in the UV region, which indicates the formation of new compounds or a breaking of these molecules into simpler ones. In the present study, the increase of the dyes solution conductivity after ozonation may serve as an indirect confirmation of sulphate and nitrate ions accumulation. On the other hand, sulphate, nitrate and oxalate ions were identified as final accumulated products and such compounds are classified as the final reaction products. Perez, Poznyak, and Chairez (2013) reported final degradation products of ozonation of azo dyes have been identified to be sulphate, nitrate, formate and oxalate.

\subsection{Observation on combined process for the treatment of azo dye wastewater}

The results showed that the combined process in which ozonation and anaerobic biodegradation play a major role in 
Table 2

Organic contents removal after combined process.

\begin{tabular}{|c|c|c|c|c|c|}
\hline Parameters & Original dye solution & $\begin{array}{l}\text { After } 25 \text { min ozonation } \\
\text { process }\end{array}$ & $\begin{array}{l}\text { Influent for UASB (ozonated } \\
\text { dye solution \& synthetic } \\
\text { domestic w/w in } 1: 1 \text { ratio) }\end{array}$ & $\begin{array}{l}\text { Effluent of UASB } \\
\text { reactor }\end{array}$ & $\begin{array}{l}\text { Overall \% } \\
\text { removal }\end{array}$ \\
\hline \multicolumn{6}{|l|}{ Reactive Black $5^{\mathrm{a}}$} \\
\hline $\mathrm{pH}$ at $25^{\circ} \mathrm{C}$ & 10.13 & 3.3 & $7.52 \pm 0.045$ & $8.49 \pm 0.411$ & - \\
\hline COD (mg/L) & $426.66 \pm 0.54$ & $426.66 \pm 0.36$ & $478.0 \pm 3.00$ & $40.29 \pm 2.46$ & 90 \\
\hline $\mathrm{BOD}(\mathrm{mg} / \mathrm{L})$ & ND & 173 & 193 & 18 & - \\
\hline TOC (mg/L) & 173.94 & 132.2 & 149 & 27.63 & 84 \\
\hline $\mathrm{BOD}_{5} / \mathrm{COD}$ ratio & ND & 0.41 & 0.41 & 0.42 & - \\
\hline Color (Pt-Co scale) & ND & 10 & BDL & 10 & - \\
\hline $\mathrm{COD} / \mathrm{TOC}$ ratio & 2.45 & 3.22 & 3.22 & 1.54 & - \\
\hline Conductivity $(\mathrm{mS} / \mathrm{cm})$ at $25^{\circ} \mathrm{C}$ & 1.935 & 2.35 & 1.2 & 1.1 & - \\
\hline
\end{tabular}

a Dye concentration: $1500 \mathrm{mg} / \mathrm{L}$.

reduction of color and COD of the dye wastewater. It has also observed that longer ozonation time is required to degradation of high concentration of Reactive Black 5 dye molecules. This is immensely affecting the process cost. Marco, Esplugas, and Saum (1997) reported that total mineralization through oxidation process is highly expensive whereas a combination of the oxidation process and biological option would be a cheaper method for degradation of total organics. Thus combined treatment to reduce the cost of the wastewater treatment process by ozonation, anaerobic treatment process by UASB reactor was used along with ozonation in this study. Ozonation of landfill leachate was proven to as the pre-treatment enhance biological treatment efficiency with total removal rate was $71.94 \%$ (Qiao, 2012). Combined treatment reduced the COD level much more significantly, which is about $90 \%$. It also reduces TOC remarkably shown in Figure 8. The color showed less than 10 on $\mathrm{Pt}-\mathrm{Co}$ scale has shown in Figure 9. Table 2 shows organic contents removal after combined process. Ozonation as a pre-treatment for combined chemicalbiological treatment is a potential process for enhanced color removal efficiencies greater than $96 \%$ were obtained (De Souza et al., 2010). Wang, Chen, Gu, Wang, and Qian (2008) reported aerated filter biological process as post-treatment after ozonation were used to treat textile-washing wastewater. The result showed that the influent qualities were COD about $80 \mathrm{mg} / \mathrm{L}$ and

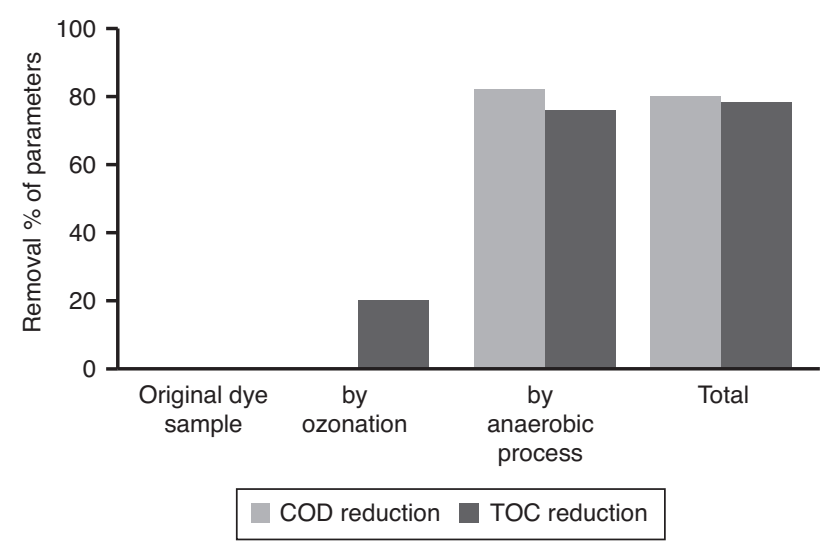

Fig. 8. Decline in COD and TOC after combined process.

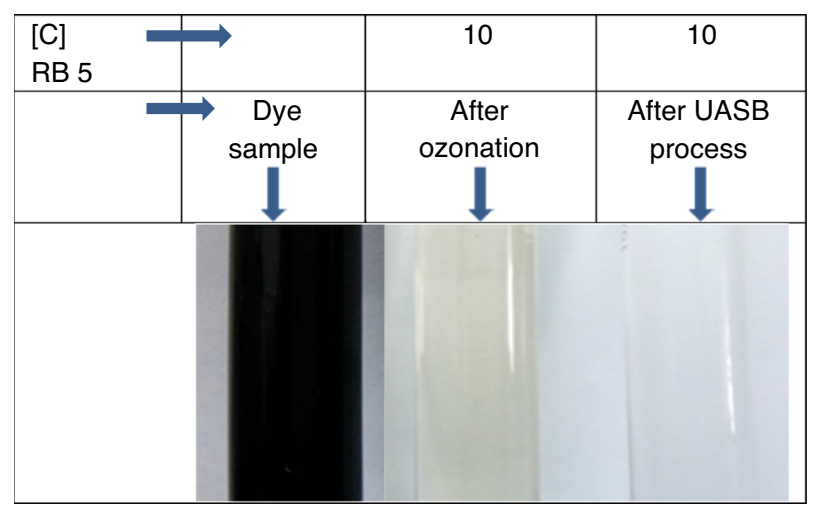

Fig. 9. Color removal after combined treatment.

color 16 degree, after combined process the effluent qualities of COD less than $30 \mathrm{mg} / \mathrm{L}$ and color 2 degree respectively.

\section{Conclusions}

A new combined and economic process was developed using ozonation and subsequent anaerobic process for treatment of dye wastewater. This combined process achieved $90 \%$ of total COD and $84 \%$ of total TOC reduction. It was also observed that for reduction of high COD, color and TOC required, longer ozonation time which affected the entire cost of the treatment. Thus anaerobic biodegradation by UASB reactor have been used along with ozonation to reduce the COD and TOC level as well as to optimize the ozonation treatment process. The operational parameters like $\mathrm{pH}$, conductivity, color and total organic carbon (TOC) were also analyzed and results showed that the initial $\mathrm{pH}$ value decreased with ozonation contact time, which indicated that the generation of by-products with acidic nature (inorganic anions and organic acids) as a result of oxidation by ozone. The dye concentration decreases with increases in ozonation time. Ozonation treatment leads to a dye removal up to $94 \%$ of the initial concentration in few minutes $(<25 \mathrm{~min})$ and color removal showed less than 10 on $\mathrm{Pt}-\mathrm{Co}$ scale. Ozonation resulted enhancement of $\mathrm{BOD}_{5} / \mathrm{COD}$ ratio of the dye solutions. The ozonized dye solution showed the presence of organic anion like oxalate ions and inorganic anions (sulphates and nitrates) as final degradation by-products. 


\section{Conflict of interest}

The authors have no conflicts of interest to declare.

\section{Acknowledgement}

We acknowledge the help and support provided by MNNIT Allahabad to complete the present work.

\section{References}

Abidin, C. Z. A., \& Ridwan, F. M. (2011). Characteristic of COD and colour removal of azo dye in ozonation and biological treatment. National Postgraduate Conference (NPC), Kuala Lumpur, 1-5.

Abidin, C. Z. A., Fahmi, M. R., Soon-An, O., Makhtar, S. N. N. M., \& Rahmat, N. R. (2015). Decolourization of an azo dye in aqueous solution by ozonation in a semi-batch bubble column reactor. Science Asia, 41, 49-54.

Alvarez, P. M., Pocostales, J. P., \& Beltran, F. J. (2011). Granular activated carbon promoted ozonation of a food-processing secondary effluent. Journal of Hazardous Materials, 185(2), 776-783.

Marco, A., Esplugas, S., \& Saum, G. (1997). How and why combine chemi$\mathrm{cal}$ and biological processes for wastewater treatment. Water Science and Technology, 35(4), 321-327.

Buehler, R. E., Staehelin, J., \& Hoigne, J. (1984). Ozone decomposition in water studied by pulse radiolysis. 1. Perhydroxyl $\left(\mathrm{HO}_{2}\right)$ /hyperoxide $\left(\mathrm{O}_{2}{ }^{-}\right)$ and $\mathrm{HO}_{3} / \mathrm{O}_{3}{ }^{-}$as intermediates. The Journal of Physical Chemistry, 88(12), 2560-2564.

Constapel, M., Schellentriager, M., Marzinkowski, J. M., \& Gab, S. (2009). Degradation of reactive dyes in wastewater from the textile industry by ozone: Analysis of the products by accurate masses. Water Research, 43(3), $733-743$.

De Souza, S. M. D. A. G. U., Bonilla, K. A. S., \& De Souza, A. A. U. (2010). Removal of COD and color from hydrolyzed textile azo dye by combined ozonation and biological treatment. Journal of Hazardous Materials, 179(1-3), 35-42.

Fahmi, M. R., Abidin, C. Z. A., \& Rahmat, N. R. (2011). Characteristic of colour and COD removal of azo dye by advanced oxidation process and biological treatment, international conference on biotechnology and environment management. IPCBEE, 18, 13-18.

Fahmi, R., Abidin, C. Z. A., \& Rahmat, N. R. (2010). Multi-stage ozonation and biological treatmentfor removal of azo dye industrial effluent. International Journal of Environmental Science and Development, 1(2), 193-198.

Ganesh, P. S., Ramasamy, E. V., Gajalakshmi, S., Sanjeevi, R., \& Abbasi, S. A. (2007). Studies on treatment of low-strength effluents by UASB reactor and its application to dairy industry wash waters. Indian Journal of Biotechnology, 6, 234-238.

Gharbani, P., Tabatabaii, S. M., \& Mehrizad, A. (2008). Removal of Congo red from textile wastewater by ozonation. International Journal of Environmental Science \& Technology, 5(4), 495-500.

Guo, Y., Yang, L., Cheng, X., \& Wang, X. (2012). The application and reaction mechanism of catalytic ozonation in water treatment. Journal of Environmental and Analytical Toxicology, 2(7), 1-6.
Langlais, B., Reckhow, D. A., \& Brink, D. R. (1991). Ozonation in water treatment applications and engineering, cooperative research report, AWWRF and compagnie generale des eaux. Lewis Publishers.

Punzi, M., Nilsson, F., Anbalagan, A., Svensson, B. M., Jönsson, K., Mattiasson, B., et al. (2015). Combined anaerobic - ozonation process for treatment of textile wastewater: Removal of acute toxicity and mutagenicity. Journal of Hazardous Materials, 292, 52-60.

Paprocki, A., Dos Santos, H. S., Hammerschitt, M. E., Pires, M., \& Azevedo, C. M. N. (2010). Ozonation of Azo Dye Acid Black 1 under the Suppression Effect by Chloride Ion. Journal of the Brazilian Chemical Society, 21(3), 452-460.

Perez, A., Poznyak, T., \& Chairez, I. (2013). Effect of additives on ozonebased decomposition of Reactive Black 5 and Direct Red 28 dyes. Water Environment Research, 85(4), 291-300.

Qiao, Y. (2012). Ozone pre-treatment to enhance anaerobic degradation of refractory landfill leachate organics M.tech thesis. The Florida State University.

Selcuk, H. (2005). Decolourization and detoxification of textile wastewater by ozonation and coagulation process. Dyes and Pigments, 64(3), 217-222.

Siles, J. A., García-García, I., Martín, A., \& Martín, M. A. (2011). Integrated ozonation and biomethanization treatments of vinasse derived from ethanol manufacturing. Journal of Hazardous Materials, 188(1), 247-253.

Somensi, C. A., Simionatto, E. L., Bertoli, S. L., Wisniewski, A., \& Radetski, C. M. (2010). Use of ozone in a pilot-scale plant for textile wastewater pre-treatment: Physico-chemical efficiency, degradation by-products identification and environmental toxicity of treated wastewater. Journal of Hazardous Materials, 175(1), 235-240.

Staehelin, J., \& Hoigne, J. (1985). Decomposition of ozone in water in the presence of organic solutes acting as promoters and inhibitors of radical chain reactions. Environmental Science and Technology, 19(12), 1206-12013.

Sundrarajan, M., Vishnu, G., \& Joseph, K. (2007). Ozonation of light shaded exhausted reactive dye bath for reuse. Dyes and Pigments, 75(2), 273-278.

Tehrani-Bagha, A. R., Mahmoodi, N. M., \& Menger, F. M. (2010). Degradation of a persistent organic dye from coloured textile wastewater by ozonation. Desalination, 260(1), 34-38.

Venkatesh, S., Quaff, A. R., Venkatesh, K., \& Pandey, N. D. (2014). Decolourization and mineralization of C.I. Direct Red 28 azo dye by ozonation. Deaslination and Water Treatment, 52, 1-11.

Venkatesh, S., Quaff, A. R., Venkatesh, K., \& Pandey, N. D. (2015). Impact of ozonation on decolourization and mineralization of azo dyes: Biodegradability enhancement, by-products formation, required energy and cost. $J r$. of Ozone: Science \& Engineering, 37(5), 420-430.

Wang, X. J., Chen, S. L., Gu, X. Y., Wang, K. Y., \& Qian, Y.Z. (2008). Biological aerated filter treated textile-washing wastewater for reuse after ozonation pre-treatment. Water Science and Technology, 58(4), 921-923.

Yasar, A., \& Tabinda, A. B. (2010). Anaerobic treatment of industrial wastewater by UASB reactor integrated with chemical oxidation processes; an overview. Polish Journal of Environmental Studies, 19(5), 1051-1061.

Zhang, F. F., Yediler, A., \& Liang, X. (2007). Decomposition pathways and reaction intermediate formation of purified, hydrolysed azo reactive dye C.I. Reactive Red 120 during ozonation. Chemosphere, 67(4), 712-717.

Zhu, W. (2010). Ozone-based decolourization of food colourants: Characterization and application to fruit leather recycling Master thesis. 